\title{
Title VII in the University: The Difference Academic Freedom Makes
}

\author{
Susan L. Pacholski
}

Title VII of the Civil Rights Act of 1964 forbids employers to discriminate on the basis of race, color, religion, sex, or national origin. ${ }^{1}$ Originally, Congress exempted educational institutions from liability under the Act. ${ }^{2}$ In 1972, however, Congress removed this exemption ${ }^{3}$ because of concerns about discrimination in the field of education, manifested in part by the lack of women and minorities in higher-ranking academic positions. ${ }^{4}$ The federal courts are uneasy with the extension of Title VII to academic insti-

† B. A. 1986, Carleton College; J.D. 1992, The University of Chicago.

- The relevant section of the Act, 42 USC $\$ 2000 \mathrm{e}-2$ (a) provides:

It shall be an unlawful employment practice for an employer-

(1) ... to discriminate against any individual with respect to his compensation, terms, conditions, or privileges of employment, because of such individual's race, color, religion, sex, or national origin; or

(2) to limit, segregate, or classify his employees ... in any way which would deprive or tend to deprive any individual of employment opportunities or otherwise adversely affect his status as an employee, because of such individual's race, color, religion, sex, or national origin.

Civil Rights Act of $1964 \S 703$, Pub L No 88-352, 78 Stat 255 (1964), codified at 42 USC $\$ \S 2000 \mathrm{e}-1$ et seq (1988).

${ }^{2}$ Congress exempted "educational institution[s] with respect to the employment of individuals to perform work connected with the educational activities of such institution." Civil Rights Act of $1964 \S 703,78$ Stat 255.

3 Equal Employment Opportunity Act of 1972, Pub L No 92-261, 86 Stat 103, codified at 42 USC $\$ 2000 \mathrm{e}-1$ (1988).

4 The House Committee Report that accompanied the 1972 amendments stated that: Discrimination against minorities and women in the field of education is as pervasive as discrimination in any other area of employment. In the field of higher education, the fact that black scholars have been generally relegated to all-black institutions, or have been restricted to lesser academic positions when they have been permitted entry into white institutions is common knowledge. Similarly, in the area of sex discrimination, women have long been invited to participate as students in the academic process, but without the prospect of gaining employment as serious scholars.

When they have been hired into educational institutions, particularly in institutions of higher education, women have been relegated to positions of lesser standing than their male counterparts.

HR Rep No 92-238, 92d Cong, 2d Sess 19-20 (1971), in 1972 USCCAN 2137, 2155. 
tutions unaccustomed to the degree of judicial intervention required by Title VII inquiries and remedies. ${ }^{5}$

Courts in the United States have traditionally exercised restraint in cases involving the academic decisions of colleges and universities. ${ }^{6}$ Judges and scholars have argued that colleges and universities exist on a plane separate from larger society, ${ }^{7}$ and that decisions affecting the rights of persons within academic institutions should be subject to minimal scrutiny by courts of law. ${ }^{8}$ In the name of "academic freedom," the Supreme Court has shrouded academic decisions with limited First Amendment protection from political interference. ${ }^{9}$

By granting college and university employees the right to sue their employers, however, Title VII seems to mandate a departure from traditional judicial deference to universities. Judical deference to universities in Title VII cases threatens to subvert Title VII's policy of "complete relief."

- See, for example, Smith $v$ University of North Carolina, 632 F2d 316, 345-46 (4th Cir 1980) ("University employment cases have always presented a decisional dilemma for the courts."); Faro v New York University, 502 F2d 1229, 1231-32 (2d Cir 1974) ("education and faculty appointments at a university level are probably the least suited for federal court supervision"); Ford v Nicks, 741 F2d 858, 864 (6th Cir 1984) ("federal courts have generally deferred to the decisions of college and university officials in whether to grant tenure"). See also Labat $v$ Board of Higher Education of City of New York, 401 F Supp 753, 757 (S D NY 1975); Peters v Middlebury College, 409 F Supp 857, 868 (D Vt 1976).

- John DeWitt Gregory, Secrecy in University and College Tenure Deliberations: Placing Appropriate Limits on Academic Freedom, 16 UC Davis L Rev 1023, 1034-36 (1983). See also Regents of the University of Michigan $v$ Ewing, 474 US 214, 225 (1985) (refusing to overturn university's decision to dismiss a student from his program); Green $v$ Board of Regents of Texas Tech University, 474 F2d 594, 595 (5th Cir 1973) (refusing to overturn university's decision to deny tenure); EEOC v University of Notre Dame Du Lac, 715 F2d 331 (7th Cir 1983) (refusing to compel disclosure of peer review documents); Kumar $v$ Board of Trustees, University of Massachusetts, 774 F2d 1, 12 (1st Cir 1985) (Campbell concurring) (warning that "courts must be extremely wary of intruding into the world of university tenure decisions").

7 J. Peter Byrne, Academic Freedom: A "Special Concern of the First Amendment," 99 Yale L J 251, 254 (1989) ("universities are fundamentally different from business corporations, government agencies, or churches .... universities require legal provisions tailored to their own goals and problems").

Id at 323-31.

- See Regents of the University of California v Bakke, 438 US 265, 311-15 (1978) (invalidating admission program that reserved places for minorities, but reaffirming right of universities to consider race in admissions decisions); Ewing, 474 US at 226. But see Matthew W. Finkin, On "Institutional" Academic Freedom, 61 Tex L Rev 817, 818 (1983) (suggesting that the concerns for institutional autonomy are not coincident with.concerns for academic freedom).

${ }^{20}$ Franks v Bowman Transportation Co., Inc., 424 US 747, 764 (1976). 
victim of discrimination "in the situation he would have occupied had the wrong not been committed."11

Nevertheless, when a plaintiff proves a discriminatory denial of tenure, some courts have interpreted academic freedom to prohibit a remedy of reinstatement with tenure. ${ }^{12}$ Many other courts have stated that academic decisionmakers should be accorded special deference in Title VII cases. ${ }^{13}$

This Comment examines the appropriate scope of judicial concern for academic freedom in the remedial phase of a Title VII suit where the plaintiff has proven that she was discriminatorily denied tenure. The Comment argues that in tenure denial cases, academic freedom should not prevent courts from awarding a successful plaintiff reinstatement with tenure. The Supreme Court has made clear that judicial solicitude for academic freedom stops at the borderline of legitimate academic decisionmaking. Title VII actions have been designed to determine whether an employment decision was based on discriminatory, rather than legitimate, criteria.

Although a university might fail to muster evidence of what really was a legitimate academic reason for tenure denial, compensating for this risk by categorically refusing to reinstate successful plaintiffs with tenure creates a risk of denying the plaintiff's academic freedom. Since a university's academic freedom exists in part to safeguard professors' academic freedom, emphasizing the university's interest at the expense of the individual educator disserves the justification for the institution's academic freedom.

Section I of this Comment examines the Supreme Court's development of the academic freedom doctrine, and differentiates individual from institutional academic freedom. This Section also

${ }^{11}$ Albemarle Paper Co. v Moody, 422 US 405, 418-19 (1975), quoting Wicker v Hoppock, 73 US (6 Wall) 94, 99 (1867).

${ }_{22}$ Gutzwiller v Fenik, 860 F2d 1317, 1333 (6th Cir 1988); Gurmankin v Constanzo, 626 F2d 1115, 1125-26 (3d Cir 1980).

${ }^{13}$ See, for example, Lieberman $v$ Gant, 630 F2d 60, 67 (2d Cir 1980) (courts should not sit as "Super-Tenure Review Committees"); Namenwirth $v$ Board of Regents of the University of Wisconsin System, 769 F2d 1235, 1243 (7th Cir 1985) ("It is not our place to question the significance or validity of [faculty committee] conclusions .... where it is a matter of comparing qualification against qualification, the plaintiff is bound to lose."); Faro, 502 F2d at 1231-32 ("Of all fields, which the federal courts should hesitate to invade and take over, education and faculty appointments at a University level are probably the least suited for federal court supervision."). Many commentators have noted the inefficacy of Title VII in the educational context, which may arise from this excess of deference. See, for example, Richard J. Yurko, Judicial Recognition of Academic Collective Interests: A New Approach to Faculty Title VII Litigation, 60 BU L Rev 473, 482 (1980) ("The overwhelming majority [of Title VII faculty members] have lost in court."); Comment, The Ineffectiveness of Title VII in Tenure Denial Decisions, 36 DePaul L.Rev 259 (1987). 
describes the extent to which the academic freedoms of the professor and the university overlap. Section II presents the varying accomodations of the federal courts to concerns of academic freedom in Title VII litigation over tenure denial. Section III argues that academic freedom concerns should not constrain judges in ordering complete relief in tenure denial cases. In most cases, a plaintiff's success will mean that no legitimate academic reason existed for the denial of tenure. In cases where doubt lingers as to whether a legitimate reason existed, a possibility remains that a qualified woman or minority was discriminatorily denied the academic freedom provided by tenure. Therefore, in such cases the dictates of Title VII, calling for full relief, should govern.

\section{The Doctrine of Academic Freedom}

Academic freedom has been described as "that aspect of intellectual liberty concerned with the peculiar institutional needs of the academic community."14 The academic freedom of university professors and researchers is generally understood to be freedom from political, ecclesiastical, or administrative interference with investigation, discussion, and publication in their field of study..$^{16}$ In addition, universities as corporate bodies have an interest in academic decisionmaking reasonably free of interference by the courts or the state. Although academic freedom is not a specifically enumerated right, the Supreme Court has stated that academic freedom of professors and universities is a "special concern" of the First Amendment. ${ }^{16}$

The Court has sometimes justified academic freedom in utilitarian terms, stating that protection for both individuals and institutions is necessary to promote "that robust exchange of ideas which discovers truth out of a multitude of tongues,"17 and to produce a citizenry willing and able to involve itself in governing the polity: "[t]o impose any strait jacket upon the intellectual leaders in our colleges and universities would imperil the future of our $\mathrm{Na}$ -

16 Developments in the Law-Academic Freedom, 81 Harv L Rev 1045, 1048 (1968).

15 See Fritz Malchup, On Some Misconceptions Concerning Academic Freedom, reprinted in Louis Joughin, ed, Academic Freedom and Tenure 178 (Wisconsin, 1969); Will Herberg, On the Meaning of Academic Freedom, in Valerie Earle, ed, On Academic Freedom 1 (American Enterprise Institute, 1971), citing Arthur O. Lovejoy Academic Freedom, in Edwin R.A. Seligman, editor-in-chief, 1 Encyclopaedia of the Social Sciences 384 (MacMillan, 1930). This notion of freedom is bounded by the limits of professional competence and ethical behavior.

${ }^{16}$ Ewing, 474 US at 226, citing Keyishian v Board of Regents, 385 US 589, 603 (1967).

17 Keyishian, 385 US at 603 (citation ommitted). 
tion." "I8 In a less utilitarian sense, the Court has also credited academic freedom with promoting allegiance to open inquiry: "teachers and students must always remain free to inquire, to study and to evaluate, to gain new maturity and understanding; otherwise our civilization will stagnate and die."19

Individual academic freedom finds protection in the courts and in contractual obligations and limitations on the university that are encouraged and enforced by the American Association of University Professors. Institutional academic freedom also finds its protection in the courts, where it becomes a thumb on the scales in favor of appropriate autonomous decisionmaking. These interests sometimes clash in cases where university professors bring claims against their universities. In weighing the interests of the disputants in such cases, courts should remember the overarching purpose common to both institutional and individual academic freedom: to promote the freedom of intellectual inquiry and debate, whether for utilitarian or symbolic purposes. This Section examines the nature and scope of individual and institutional academic freedom, as defined in Supreme Court case law and scholarly literature. This discussion should prepare the reader to judge whether the goals of Title VII must give way to academic freedom concerns in tenure denial cases.

\section{A. Individual Academic Freedom}

Individual academic freedom is protected to a limited extent by the courts, as well as in professors' contracts with the university. The courts protect state university professors' due process and First Amendment rights against infringement by the state university administration, as well as the constitutional rights of all university professors against incursions by the state. The American Association of University Professors sets forth recommended terms for professorial contracts and has an administrative apparatus to hear disputes.

Threats to individual academic freedom come from the state as well as the university administration. The Supreme Court has safeguarded the academic freedom interest of state university professors through the medium of the free speech and assembly clauses of the First Amendment and the Due Process Clause of the

\footnotetext{
${ }_{18}$ Sweezy u New Hampshire, 354 US 234, 250 (1957). See also Minnesota State Board for Community Colleges v Knight, 465 US 271, 293 (1984) (Marshall concurring).

${ }^{19}$ Sweezy, 354 US at 250.
} 
Fourteenth Amendment. ${ }^{20}$ The Cold War era produced a number of cases involving state loyalty oath requirements and procedures, imposed on faculty either by state officials or state educational administrators. Noting the importance of "that free play of the spirit which all teachers ought especially to cultivate and practice,"21 the Court, in Keyishian v Board of Regents, struck down as unconstitutionally vague a New York law providing for dismissal from the public school system for "treasonable or seditious" utterances or acts. ${ }^{22}$ During the same period the Court struck down as vague or violative of due process numerous state loyalty oaths and loyalty oath procedures. ${ }^{23}$ In Sweezy $v$ New Hampshire, ${ }^{24}$ the Court reversed a contempt conviction of a lecturer who refused to disclose the content of an allegedly "subversive" university lecture. ${ }^{25}$

The Court has also upheld the First Amendment right of state university faculty to speak out on political matters without fear of losing their jobs. In Pickering $v$ Board of Education, ${ }^{26}$ the Court ordered reinstatement of a public school teacher fired for protected expression on issues of legitimate public concern. ${ }^{27}$ ?

The First Amendment and due process rights of academics in these cases are not in substance different from those of other state employees. However, individuals in academic institutions have been specifically targeted for ideological controls by state statutes, ${ }^{28}$ and the Supreme Court has declared that infringement of

${ }^{20}$ Walter P. Metzger, Profession and Constitution: Two Definitions of Academic Freedom in America, 66 Tex L Rev 1265, 1318 (1988).

21 Keyishian, 385 US at 601, citing Wieman v Updegraff, 344 US 183, 195 (1952) (Frankfurter concurring).

${ }^{22}$ Id at 603-04. See id at 597-98 for language from the New York statute.

${ }^{23}$ Whitehill $v$ Elkins, 389 US 54, 57-62 (1967) (state loyalty oath held to be unconstitutionally vague because it lacked a clear delineation between permissible and impermissible conduct in the sensitive area of academic freedom); Baggett $v$ Bullitt, 377 US 360, 366 (1964) (holding that state loyalty oath was unconstitutionally vague); Wieman $v$ Updegraff, 344 US 183, 187-91 (1952) (state loyalty oath procedure violated faculty members' due process rights).

354 US 234 (1957).

${ }^{25}$ Sweezy, 354 US at 238-45, 254-55. See also Slochower v Board of Higher Education, 350 US 551, 553-55 (1956) (summary dismissal of college professor for refusal to answer questions about Communist Party membership violated professor's due process rights).

28 391 US 563 (1968).

${ }_{27}$ Id at 568-73. See also Mt. Healthy City School District Board of Education v Doyle, 429 US 274, 283-87 (1977) (teacher's right of free expression is violated where evidence shows that the employer would have retained the teacher but for the exercise of her constitutional rights).

28 See Keyishian, 385 US at 593 ( $\$ 3021$ of the New York Education Law provided that the utterance of treasonable or seditious words or acts was a ground for dismissal from the public school system). 
constitutional rights in the academy is particularly troubling: "The vigilant protection of constitutional freedoms is nowhere more vital than in the community of American schools." 29

Constitutionally protected rights against government prescriptions of orthodoxy in state university speech are a necessary but not sufficient assurance that all educators will remain free to "examine, question, modify or reject traditional ideas and beliefs." The American Association of University Professors (AAUP) has established and maintained standards for university compliance with professors' academic freedom: full freedom in research and publication of results, and freedom in the classroom to discuss her subject within the limits of her subject matter. ${ }^{31}$ The AAUP vindicates academic freedom rights by mediating disputes, investigating challenged procedures, and applying the sanction of censure to those universities which have violated principles of academic freedom and tenure.$^{32}$ Educators, therefore, may take contractual, Title VII, or constitutional claims to court, or they may rely on the AAUP.

Tenure, however, is not generally considered an aspect of academic freedom..$^{33}$ Tenure is a contractual right, providing that a professor can only be dismissed for good cause adequately proved at a fair hearing. ${ }^{34}$ Although nontenured faculty should enjoy academic freedom as well, many academics have argued, and at least one circuit court has recognized, that tenure's promise of freedom from arbitrary dismissal helps assure the uninhibited pursuit of knowledge. ${ }^{35}$ Nontenured faculty may face institutional unwillingness to renew contracts for ideological reasons masked as academic

28 Shelton v Tucker, 364 US 479, 487 (1960).

30 Sweezy, 354 US at 262 (Frankfurter concurring).

${ }^{31}$ American Association of University Professors (AAUP), 1940 Statement of Principles on Academic Freedom and Tenure, reprinted in Policy Documents and Reports 3 (American Association of University Professors, 1984). Also reprinted in Joughin, ed, Academic Freedom and Tenure at 33 (cited in note 15).

${ }^{32}$ Ralph F. Fuchs, Academic Freedom-Its Basic Philosophy, Function, and History, reprinted in Joughin, ed, Academic Freedom and Tenure at 242, 253.

${ }^{33}$ See Herberg, On the Meaning of Academic Freedom, reprinted in Earle, ed, On Academic Freedom at 2 (cited in note 15); Byrne, 99 Yale $\mathrm{L} J$ at $265-66$ (cited in note 7).

${ }^{36}$ AAUP, 1940 Statement of Principles and Interpretive Comments, reprinted in Policy Documents and Reports at 3.

${ }^{36}$ See Fritz Malchup, Some Misconceptions Concerning Academic Freedom, reprinted in Joughin, ed, Academic Freedom and Tenure at 181; Byrne, 99 Yale L J at 266; Howard Mumford Jones, The American Concept of Academic Freedom, reprinted in Joughin, ed, Academic Freedom and Tenure at 231. See also Brown v Trustees of Boston University, 891 F2d 337, 360 (1st Cir 1989). 
judgments, ${ }^{36}$ and will have a hard time disproving claims of an academic basis for dismissal. Furthermore, the educator's peers may not even be consciously aware of the effect of their ideological biases on their "academic" evaluation..$^{37}$ Once a professor has tenure, she can be dismissed only for good cause, such as incompetence or neglect of duty, which must be adequately proved at a fair hearing. ${ }^{38}$

\section{B. Institutional Academic Freedom}

The Court has stated that "[a]cademic freedom thrives not only on the independent and uninhibited exchange of ideas among teachers and students, but also, and somewhat inconsistently, on autonomous decisionmaking by the academy itself." ${ }^{39}$ In cases implicating university decisionmaking processes, the Supreme Court carefully considers the interests of the university and attempts to minimize judicial and state interference with legitimate academic decisionmaking.

Adhering to a principle of respect for academic decisionmaking, ${ }^{40}$ the Court has carefully considered the university's interest in autonomous academic decisionmaking when asked to enforce a university student's First Amendment or due process rights against the university. The Court has held that a due process hearing is unnecessary to review the substance of academic decisions to dismiss students and has stated that courts should give universities a measure of discretion in student selection criteria and in regulating access to university facilities.

The Court has respected a university's discretion in dismissing students on academic grounds. ${ }^{41}$ In Regents of the University of Michigan $v$ Ewing, the Court was asked to determine whether the University's refusal to allow a medical student to retake a failed board examination denied the student due process. ${ }^{42}$ The Court

\footnotetext{
${ }^{36}$ Fritz Malchup, In Defense of Academic Tenure, reprinted in Joughin, ed, Academic Freedom and Tenure at 330 .

37 Id at 330 .

38 AAUP, 1982 Recommended Institutional Regulations on Academic Freedom and Tenure, reprinted in Policy Documents and Reports at 21, 25-26 (American Association of University Professors, 1984).

39 Ewing, 474 US at 226 n 12 (citations omitted).

10 University of Pennsylvania $v$ EEOC, 493 US 182, 199 (1990), citing Ewing, 474 US at 225 ("judges . . . asked to review the substance of a genuinely academic decision ... should show great respect for the faculty's professional judgment").

"Ewing, 474 US at 225; Board of Curators of the University of Missouri $v$ Horowitz, 435 US 78, 90 (1987).

12474 US at 221.
} 
carefully considered the circumstances under which the decision was made and held that it was made on academic grounds, and that the student's due process rights were not abridged. ${ }^{43}$ The Court declined to review the substance of the decision, stating that "when judges are asked to review the substance of a genuinely academic decision, such as this one, they should show great respect for the faculty's professional judgment." 44 However, the Court has stated that a dismissal for disciplinary reasons may call for more stringent procedural regulations than a dismissal for academic reasons. ${ }^{40}$

As part of the university's discretion in selection of a student body, the Court, in University of California $v$ Bakke, affirmed a university's discretion to consider race in admissions decisions, in order to achieve a diverse student body. ${ }^{46}$ However, the Court struck down the university's strict quota system as unnecessary to promote this interest and as violative of Bakke's equal protection rights. ${ }^{47}$

The Court has also emphasized the need to consider the special characteristics of the school environment when considering whether banning a student group from campus facilities violates students' First Amendment rights. Healy $v$ James ${ }^{48}$ suggested that students' right to free speech on campus would not be infringed by a college administrator's requiring advance affirmation of a student group's willingness to adhere to campus regulations forbidding violence. ${ }^{49}$ However, in Widmar $v$ Vincent, ${ }^{50}$ the Court held that a state university's policy of excluding religious groups from campus facilities was an impermissible content-based regulation of speech. ${ }^{51}$

In cases involving faculty selection, the Court has voiced a policy of protecting universities from state attempts to impose selection criteria. ${ }^{\mathbf{2}}$ In University of Pennsylvania $v$ EEOC, ${ }^{\mathbf{5 3}}$ the Court held that an EEOC subpoena for the disclosure of peer review documents did not interfere with the university's academic freedom.

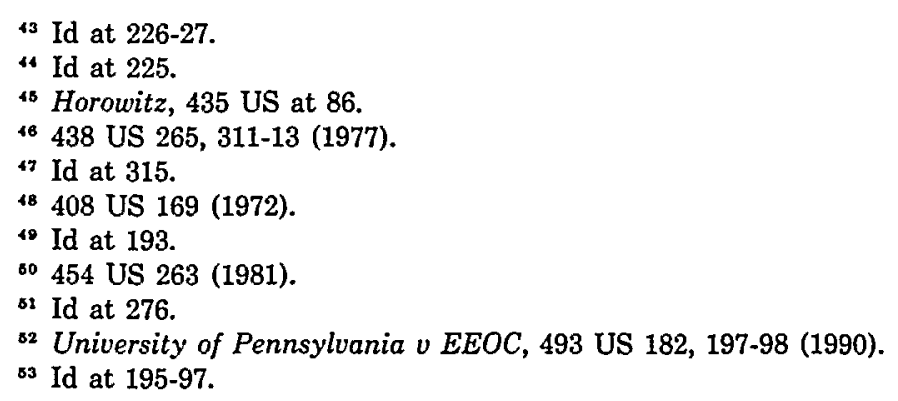


Impermissible usurpation had occurred, the U Penn Court stated, in loyalty oath cases such as Keyishian, in which the government had passed laws banning employment in public education of those who espoused communist views. ${ }^{54}$ In such cases the government had substituted its own teaching requirements for those of the university. In contrast, the EEOC subpoena did not prevent the university from using "any criteria it may wish to use, except those-including race, sex, and national origin-that are proscribed under Title VII."

\section{Academic Freedom, Title ViI, and Tenure Denial Cases in THE LOWER COURTS}

This Section introduces the relevant aspects of Title VII in tenure denial cases, and examines the different circuit courts' approaches to remedying discriminatory denials of tenure. Title VII allows employees of educational institutions to bring suit for employment practices that discriminate against them because of their race, color, religion, sex or national origin. ${ }^{56}$ If a court finds that a school has intentionally engaged in an unlawful employment practice, it may enjoin such practice, and award such affirmative action as may be appropriate. This action "may include, but is not limited to reinstatement ... with or without back pay ... or any other equitable relief as the court deems appropriate." ${ }^{57}$ Compensatory and punitive damages are available as well..$^{58}$ The Supreme Court has stated that in fashioning a remedy in Title VII cases, the lower courts have a responsibility to provide the most complete relief possible, ${ }^{88}$ and must strive to make the victim whole by placing her, as near as may be, in the situation she would have occupied had the wrong not been committed. ${ }^{60}$ The following sections describe the approaches courts have taken in tenure denial cases.

s4 Id at 198.

ss Id.

s6 42 USCS $\S 2000 \mathrm{e}-2$ (1992).

572 USCS $\$ 2000 \mathrm{e}-5(\mathrm{~g})(1992)$.

${ }^{38}$ Franks v Bowman Transportation Co., Inc., 424 US 747, 764 (1976).

so Civil Rights Act of $1991 \S 102$ (b), Pub L No 102-166, 105 Stat 1071, codified at 42 USCA $\S 1981 \mathrm{a}(\mathrm{b})$ (1992). Compensatory and punitive damages are limited by a $\$ 50,000$ to $\$ 300,000$ cap, depending on the total number of employees. Id.

${ }^{60}$ Albemarle Paper Co. v Moody, 422 US 405, 418-19 (1975). 
A. The Fair Reconsideration Approach: Two Views on Deference to Academic Institutions

In Gutzwiller v Fenik, the Sixth Circuit set forth a "fair reconsideration" standard for dealing with tenure denial cases. ${ }^{81}$ Under this standard, a plaintiff who proves she was denied tenure for discriminatory reasons is entitled only to reinstatement for reconsideration of the tenure decision. The court will reinstate with tenure only in exceptional circumstances-where the plaintiff demonstrates that she will not receive fair reconsideration by the college or university. ${ }^{62}$

The Gutzwiller court developed this standard in order to maximize the university's automony in academic decisionmaking. The court stated that in most cases an award of reinstatement with tenure would "entangle courts in matters best left to academic professionals." ${ }^{33}$ The University of Cincinnati denied Gutzwiller tenure despite her having had a book accepted for publication and good teaching reviews. ${ }^{64}$ On her $\S 1983$ claim, the jury ruled in Gutzwiller's favor based on their finding that Gutzwiller's sex was "a determining factor in the denial of tenure." " "[A] male with the identical experience, ability and qualifications ... would have been granted tenure." ${ }^{166}$ The court stated that the jury could have found on the basis of the evidence that the department chair:

intentionally treated Gutzwiller less favorably throughout the evaluation process than he treated men; that he put barriers in her path that were not encountered by men seeking tenure in the Department; that he imposed higher standards of scholarship upon Gutzwiller than upon similarly situated men; and that he intentionally engaged in a calculated effort over time to insure that Gutzwiller did not receive tenure. ${ }^{67}$

The court nevertheless directed the lower court to reinstate Gutzwiller with tenure only if the university would not fairly reconsider her tenure application. ${ }^{88}$

62 860 F2d 1317 (6th Cir 1988).

${ }^{62}$ Id at 1333.

${ }^{63}$ Id. The Gutzwiller court cited no precedent in articulating this standard.

B4 Id at 1320-21.

os These jury findings were on Gutzwiller's 42 USC $\$ 1983$ claim. The appellate court held that, in considering Gutzwiller's Title VII claim, the trial judge was bound by the jury's findings on the $\$ 1983$ claim. Id at 1333.

68 Id at 1328.

${ }^{67}$ Id at $1325-26$.

${ }^{68}$ Id at 1333. 
The Third Circuit also adopted the fair reconsideration standard, but with less emphasis on deference to academic institutions. In Kunda v Muhlenberg College, the court held that the college's asserted reason for withholding tenure from a female physical education instructor-her lack of a master's degree-was pretextual. ${ }^{69}$ The court noted that the Dean of the college, who repeatedly opposed the plaintiff's advancement, did not advise her, as he did male department members, of the necessity of obtaining a master's degree in order to receive tenure. ${ }^{70}$ Noting that the plaintiff's "achievements, qualifications, and prospects were not in dispute," college grant Kunda tenure if she attained a master's degree within two years. ${ }^{72}$

Like Gutzwiller, Kunda gives district judges discretion over whether to reinstate the successful Title VII plaintiff with tenure. The Kunda court noted that determinations about teaching ability, research scholarship, and professional stature that were not "shown to have been used as the mechanism to obscure discrimination, [] must be left for evaluation by the professionals."73

In Kunda, however, the Third Circuit adopted an attitude toward academic institutions that is less deferential than the Sixth Circuit's, noting that "[the courts'] anti-interventionist policy has rendered colleges and universities virtually immune to charges of employment bias, at least when that bias is not expressed overtly." "74 The judicial policy of deference, according to the Kunda court, "has been pressed beyond all reasonable limits, and may be employed to undercut the explicit legislative intent of the Civil Rights Act of 1964." ${ }^{\text {" }}$ Kunda expressly allows a district judge to reject the "fair reconsideration" route if she is concerned that changes in the university's financial situation, in its student enrollment, or in its faculty hiring plans might taint the reconsideration decision, or if she is concerned about "the intangible effect upon the decision because the candidate being considered was the successful party to a Title VII suit." ${ }^{8}$

69 621 F2d 532 (3d Cir 1980).

${ }^{70}$ Id at 539.

${ }^{71}$ Id at 548 .

${ }^{72}$ Id at 535.

${ }^{73}$ Id at 548.

${ }^{74}$ Id at 551, quoting Powell v Syracuse University, 580 F2d 1150, 1153 (2d Cir 1978).

${ }^{75}$ Id.

${ }^{78}$ Id at 549. 


\section{B. Reinstatement with Tenure Required}

While the Third Circuit expressed a willingness to scrutinize, more strictly than the Sixth Circuit, an institution's capacity for fair reconsideration of a prevailing plaintiff, the First Circuit rejected the fair reconsideration approach altogether. In Brown $v$ Trustees of Boston University, the First Circuit upheld an award of tenure to the plaintiff, who had proved that she had been held to a stricter standard than her male peers. ${ }^{77}$ Even though Brown received positive recommendations for the tenure decision at various levels of review, ${ }^{78}$ the provost and the president opposed her tenure application, on the ground that her only publication was a revision of her dissertation. ${ }^{79}$ Brown presented evidence that none of the department's male candidates who had received tenure had been required to write a second book, and that one candidate had not even written a first book. ${ }^{80}$ The jury found that but for sex discrimination, Brown would have been granted tenure. ${ }^{81}$

The First Circuit stated that it was "hesitant to interfere with universities' independent judgment in choosing their faculty."82 Nevertheless, the court stated emphatically that the policy of deference does not apply when the university "has been found to have impermissibly discriminated in making a tenure decision." In such cases, the university's prerogative to make tenure decisions must be subordinated to the goals embodied in Title VII."83

The Brown court flatly rejected the possibility of awarding either reinstatement for a probationary period or ordering reconsideration of the tenure decision, stating that these remedies would not make the plaintiff whole. ${ }^{84}$ Reinstatement with tenure, the court concluded, was the only way to provide the plaintiff "the most complete relief possible." ${ }^{85}$

\footnotetext{
77891 F2d 337 (1st Cir 1989).

78 Id at 341.

2s Id at 342-43.

${ }^{80}$ Id at $344 \mathrm{n} 6$.

81 Id at 360 .

s2 Id.

as Id at 359.

st Id at 360

ss Id.
} 


\section{Striking a Balance Between Trtle VII and Academic FrEedoM}

This Section argues that courts that refuse to reinstate successful academic plaintiffs with tenure unnecessarily abdicate their duty to those plaintiffs under Title VII. A court faced with the duty to enforce a university plaintiff's Title VII rights might feel concern about encroaching on the university's decisionmaking autonomy. The Title VII inquiry is designed, however, to determine whether the denial of tenure was based on legitimate academic grounds. If the plaintiff prevails, then the risk that the court will override a legitimate academic decision is slight. Furthermore, where a judge refuses to reinstate the plaintiff with tenure, the risk is equally great that the plaintiff's academic freedom will be denied. Avoiding judicial encroachment on institutional academic freedom, therefore, risks allowing the university to encroach on the academic freedom of the individual.

\section{A. Enforcing Title VII in the Academy}

Congress accompanied the extension of Title VII to academic institutions in 1972 with strong statements about the importance of eradicating employment discrimination in educational institutions. If courts are to comply with Congress's directive and grant complete relief to plaintiffs wrongly denied tenure, they must reinstate successful plaintiffs with tenure.

\section{Congress intended strong enforcement of Title VII.}

When Congress extended Title VII to colleges and universities, it did not indicate that employment discrimination in the educational context should be treated differently than other contexts. The House Committee Report accompanying the 1972 amendments simply stated, "[ $t]$ here is nothing in the legislative background of Title VII, nor does any national policy suggest itself to support the exemption of the educational institution employees ... from Title VII coverage." $" 86$ The House Committee also indicated that it thought that effects of discrimination in higher education had more serious consequences than did discrimination in other fields:

${ }^{86}$ HR Rep No 92-238, 92d Cong, 2d Sess 19-20 (1971), reprinted in 1972 USCCAN 2136, 2155. 
[D] iscrimination in educational institutions is especially critical. The Committee cannot imagine a more sensitive area than educational institutions where the Nation's youth are exposed to a multitude of ideas that will strongly influence their future development. To permit discrimination here would, more than in any other area, tend to promote misconceptions leading to future patterns of discrimination. ${ }^{87}$

Opponents of the 1972 amendment claimed that enforcement of Title VII would weaken institutions of higher education by interfering with their decisions to hire and promote faculty members. ${ }^{88}$ One Senator darkly warned that "[a]cademic freedom which is so revered by liberal thought in this country, might very well be a thing of the past if this bill passes." 89 Despite vigorous debate in the Senate, ${ }^{\circ 0}$ Congress nevertheless extended the Act to cover academic institutions. This suggests Congress's considered judgment that the need to end discrimination in educational institutions outweighs concerns for the autonomy of universities.

2. "Complete relief" requires reinstatement with tenure.

By refusing to reinstate with tenure plaintiffs who prove discrimination in the tenure process, some courts fail to provide the full relief which Title VII demands. In light of the Supreme Court's "make whole" policy"1 and the expansion of Title VII to educational institutions, the only way for courts to "make whole" plaintiffs who were wrongly denied tenure is to reinstate successful plaintiffs with tenure. ${ }^{92}$

87 Id. See also 117 Cong Rec 32105 (Sep 16, 1971) (remarks of Representative Mink) ("It is especially important that employment in our educational institutions be open to all on an equal basis, for they have an unparalleled opportunity to free the future from present discriminatory attitudes and practices. The example which our educational system sets has an incalculable impact on the attitudes and beliefs of the youth of this country, and we cannot permit discrimination to infect and damage yet another generation.").

"s 118 Cong Rec 311 (Jan 19, 1972) (remarks of Senator Ervin). See also 118 Cong Rec 4919 (Feb 22, 1972) (remarks of Senator Ervin) ("Federal judges, and members of the EEOC, are not competent to pass on the qualifications of people who teach such abstract subjects as anthropology and other subjects in institutions of higher learning.").

s2 118 Cong Rec 946 (Jan 24, 1972) (remarks of Senator Allen).

- See 118 Cong Rec 4919 (Feb 22, 1972) (remarks of Senator Javits).

" See text accompanying notes 59-60.

92 The Supreme Court has stated that "[t]he effect of the elimination of th[e] exemption was to expose tenure deliberations to the same enforcement procedures applicable to other employment decisions." University of Pennsylvania v EEOC, 493 US 182, 183 (1990). 
The costs to the educator of a denial of tenure are high. Most if not all tenure decisions are on an "up or out" basis-if the educator is not granted tenure, she is in most cases given a one-year terminal contract. ${ }^{93}$ Most educators spend between four and seven years at a university before a tenure decision. Upon re-entering the job market, the educator who has been denied tenure will be older than most other candidates. ${ }^{94}$ In addition, a denial of tenure damages an educator's reputation and will greatly inhibit the individual's chances of receiving a teaching position at another university. ${ }^{95}$

The Civil Rights Act of 1991 provides for compensatory and punitive damages for successful Title VII plaintiffs. ${ }^{96}$ Some might argue that courts should award such damages in lieu of reinstatement with tenure, especially if the University has shown itself to be hostile to the plaintiff due to race or gender. The damages available under Title VII, however, are paltry compared the earnings of a tenured faculty member during her career at a university. Backpay awards are limited by a duty to mitigate; compensatory and punitive damages allowed are limited by a $\$ 200,000$ cap. ${ }^{97}$ Tenure, on the other hand, is a life contract. To refuse reinstatement due to hostility in the university would essentially amount to a triumph for discriminatory attitudes; those who wanted to keep out minorities or women will have prevailed. Moreover, if the plaintiff would be uncomfortable with reinstatement, she has the option of requesting alternative remedies.

Finally, and most importantly, no amount of money damages can substitute for the security that tenure provides an educator. Tenure insures the intellectual independence of educators; it allows them to teach, study and publish without the fear of arbitrary dismissal. A grant of tenure means that an educator may be dismissed only for adequate cause. ${ }^{98} \mathrm{~A}$ tenured educator at a public university has constitutionally protected property rights which cannot be eviscerated without due process of law. ${ }^{99}$ Even in private

${ }^{93}$ See Delaware State College v Ricks, 449 US 250, 252-53 (1980).

94 See EEOC v Tufts Institution of Learning, 421 F Supp 152, 165 (D Mass 1975) (denial of tenure as relief will cause irreparable harm where plaintiff is older). See also Smith $v$ University of North Carolina, 632 F2d 316 (4th Cir 1980) (fact that plaintiff was older than most beginning professors was frequently commented on as cause for concern).

95 Tufts, 421 F Supp at 165.

${ }^{86}$ See text accompanying notes 57-58.

97 42 USCA § 1981a(b) (1992).

${ }^{98}$ See Lieberman $v$ Gant, 630 F2d 60, 64 n 5 (2d Cir 1980).

${ }^{28}$ Collins v Marina-Martinez, 894 F2d 474, 477 (1st Cir 1990). 
universities, in order to dismiss a tenured professor, the university must usually follow elaborate procedures, with the burden falling on the university to prove adequate cause. ${ }^{100}$ Furthermore, since the educators who are most in danger of being denied tenure on discriminatory grounds are also the most likely to research and publish in areas that challenge status quo predispositions, ${ }^{101}$ discriminatory tenure denials have external effects on the community at large, which suffers the loss of fresh ideas and perspectives. Insisting on money damages as the only remedy available to prevailing plaintiffs in tenure discrimination cases fails to address the public interest, which is better served by reinstatement with tenure where the plaintiff prefers that remedy.

The fair reconsideration remedy is also unlikely to vindicate the plaintiff's rights. First, the faculty and administrators who discriminated against the plaintiff the first time around may be the same ones making the court-ordered "nondiscriminatory" tenure decision. Because academic decisionmaking is so subjective, those with a race or sex bias might consciously ${ }^{102}$ or subconsciously ${ }^{103}$ devalue the work of a woman or minority member when re-evaluating her. The same subconscious devaluation may come into play by faculty or administrators unable to ignore the fact that the plaintiff is a successful Title VII complainant. Furthermore, faculty may well find it impossible to ignore changes in the school's financial situation, student enrollment, and the faculty hiring that may have occurred in the years since the inception of the suit. ${ }^{104}$ The likelihood of such difficulties makes a fair reconsideration of the tenure decision seem unlikely at best. The university may, of course, grant tenure to the plaintiff after a court-ordered reconsideration, either out of a desire to avoid further litigation, or out of an honest as-

${ }^{100}$ Lieberman, 630 F2d at 64 n 5.

101 Phoebe A. Haddon, Academic Freedom and Governance: A Call for Increased Dialogue and Diversity, 66 Tex L Rev 1561, 1569 (1988) ("Perspectives that challenge or contravene the status quo can become convenient targets and result in the squelching or stifling of the diversity of views that arise from alternative life experiences and thinking.").

${ }^{202}$ Rowe $v$ General Motors Corporation, 457 F2d 348, 359 (5th Cir 1972) (personnel decisions that depend almost entirely on subjective evaluation are a "ready method of discrimination" because bias can be covertly concealed with little chance of detection).

${ }^{103}$ See Mary E. Becker, Barriers Facing Women in the Wage-Labor Market and the Need for Additional Remedies: A Reply to Fischel and Lazear, 53 U Chi L Rev 934, 942 (1986) (and studies cited therein); Bernice Lott, The Devaluation of Women's Competence, $41 \mathrm{~J}$ Social Issues no 4, 43, 47 (1985) (and studies cited therein); Jomills Henry Braddock II and James M. McPartland, How Minorities Continue to be Excluded from Equal Employment Opportunities: Research on Labor Market and Institutional Barriers, $43 \mathrm{~J}$ Social Issues no 1, 5, 22 (1987).

104 See Kunda v Muhlenberg, 621 F2d 532, 549 (3d Cir 1980). 
sessment of the plaintiff's qualifications. However, Title VII's "make whole" provision ought not require successful plaintiffs to go through the decisionmaking process a second time. ${ }^{105}$

\section{B. Academic Freedom In Tenure Denial Cases}

Plaintiffs bring tenure denial suits under either the pretext or mixed motives frameworks. In both types of suits, this Section argues, the antidiscrimination principle of Title VII should outweigh the university's interest in autonomous decisionmaking.

\section{Pretext cases.}

Most Title VII tenure denial cases have proceeded under the pretext analysis. Under this analysis, plaintiffs who lack direct evidence of discriminatory intent raise the inference of discriminatory intent by exposing the employer's "legitimate" reason for tenure denial as pretextual. ${ }^{108}$ The plaintiff must make a prima facie case of discrimination, showing that (1) she belongs to a group protected under Title VII, (2) she was qualified for the position, (3) despite her qualifications, she was rejected. ${ }^{107} \mathrm{~A}$ burden of production then shifts to the employer to articulate a legitimate reason for denying the plaintiff tenure. Invariably, universities will state that the plaintiff did not meet the department's or university's standards for tenure. The plaintiff must then prove that the university's stated reason-that she was not qualified for tenure-is merely a pretext for discrimination. The plaintiff can establish pretext by showing that the university's given reasons are not worthy of belief, or that some other motive better explains the action. ${ }^{108}$ For example, the plaintiff in Brown sufficiently proved that Boston University's reasons for denying her tenure-insufficient scholarship-was pretextual in light of the fact that (1) no other candidate for tenure in the previous six years had published more than Brown, and (2) no other candidate whose dissertation had been

${ }^{105}$ Moreover, the litigation might be potentially endless. The Brown case, for example, took eight years from denial of tenure to appellate decision. As the Brown court pointed out, the jury found that " 'but for' sex discrimination, Brown would have immediately been granted tenure." Brown v Trustees of Boston University, 891 F2d 337, 360 (1989) (emphasis added). In such a case, anything less than tenure would hardly be a remedy at all.

${ }^{108}$ McDonnell Douglas Corp. $v$ Green, 411 US 792, 804 (1972); Texas Department of Community Affairs v Burdine, 450 US 248, 253 (1981).

${ }^{107}$ McDonnell Douglas, 411 US at 802.

108 See, for example, Namenwirth v Board of Regents of University of Wisconsin System, 769 F2d 1235, 1240 (7th Cir 1985). 
published and reviewed, as had Brown's, was denied tenure. ${ }^{109}$ Plaintiffs must meet a very high standard in order to show pretext. For a tenure denial reason to be found pretextual it must be obviously weak or implausible, not merely less convincing to the judge than it was to some others. According to one judge, inference of pretext is tantamount to a finding of bad faith. ${ }^{110}$

A plaintiff who exposes an employer's putatively legitimate reasons as pretextual has thus proven that the university did not deny tenure for a legitimate academic reason. ${ }^{111}$ Thus, a court that awards reinstatement with tenure does not thereby substitute its own academic criteria for the university's. As the Brown court stated, "the [district] court would have erred had it told the jury that it should find for Brown if it found that she deserved tenure." $" 112$ Rather, the court or the jury must find that absent the discriminatory animus, the plaintiff would have received tenure-that is, that "but for discriminatory animus the University would have made a different decision regarding tenure."113 Reinstatement for fair reconsideration is redundant: the plaintiff has already proven that the university did not deny tenure for legitimate reasons.

\section{Mixed motive cases.}

In a mixed motive case, the plaintiff must show that gender or race played a motivating part in the denial of tenure. ${ }^{114}$ The plaintiff relies on direct evidence to establish discriminatory animus, whereas in pretext cases she indirectly raises an inference of such purpose. ${ }^{115}$ Under the 1991 Civil Rights Act, the court may then award the plaintiff compensatory and punitive damages, as well as an injunction and declaratory judgment against the university. The

\footnotetext{
109 Brown, 891 F2d at 345.

${ }^{110}$ Kumar v Board of Trustees, University of Massachusetts, 774 F2d 1, 18 (1st Cir 1985) (Campbell concurring).

${ }^{111}$ International Brotherhood of Teamsters v United States, 431 US 324, 335-36 n 15 (1977) (noting that in disparate treatment cases, "[p]roof of discriminatory motive is critical").

112 Brown, $891 \mathrm{~F} 2 \mathrm{~d}$ at 354.

113 Id.

11 Price Waterhouse v Hopkins, 490 US 228, 241 (1989).

11 See Trans World Airlines, Inc. $v$ Thurston, 469 US 111, 121 (1985) (direct evidence of discrimination establishes a prima facie case of discrimination); Fields $v$ Clark University, 817 F2d 931, 935 (1st Cir 1987) (professor who proved that unlawful discrimination was a motivating factor in denial of tenure was not required to prove that it was a "but for" cause); Goodman v Lukens Steel Co., 777 F2d 113, 130 (3d Cir 1985) (when direct evidence of discrimination brought forward, prima facie case has been established).
} 
university may avoid an award of back pay and reinstatement by proving that even if it had not taken the plaintiff's race or gender into account, it still would have denied the plaintiff tenure. ${ }^{116}$ As in pretext cases, the defendant will present evidence that the plaintiff was not qualified for tenure, but in mixed motives cases the defendant must prove this assertion and not merely articulate it. Because the defendant must prove this negative proposition, there is a threat of the court's intruding on a legitimate academic decision that the university simply cannot substantiate with evidence. There may be cases in which the defendant simply cannot muster sufficient evidence at trial for what was a legitimate academic decision to deny tenure. Even so, this possibility should not stop courts from reinstating plaintiffs with tenure.

\section{CONCLUSION}

The Supreme Court has cautioned that judges must show "great respect for the faculty's professional judgment" when they are "asked to review the substance of a genuinely academic decision."117 However, the Court has also suggested that universities are granted this measure of freedom in order that "teachers and students [will] remain free to inquire, to study and to evaluate, to gain new maturity and understanding." ${ }^{118}$ Refusing to reinstate a plaintiff with tenure poses a risk that the court will assist university administrators in denying a qualified teacher the opportunity to freely think, discuss, and publish because of her race or gender. A refusal to reinstate with tenure creates the additional problem of thwarting Title VII's policy of complete relief ${ }^{119}$ and congressional intent to extend complete relief to educators against whom educational institutions have discriminated. A judicial policy of deference to the institution that bars reinstatement with tenure, even when complete relief would require it, seems wrong.

${ }^{126}$ Price Waterhouse, 490 US at 242.

${ }^{117}$ Ewing, 474 US at 225.

118 Sweezy, 354 US at 250.

${ }^{119}$ See Albemarle Paper Co. v Moody, 422 US 405, 421 (1975) (once Title VII liability has been imposed, a court should deny "make whole" relief "only for reasons which, if applied generally, would not frustrate the central statutory purposes of eradicating discrimination throughout the economy and making persons whole for injuries suffered through past discrimination"). 